\title{
Evaluation of Fecal Contamination by Human and Ruminant Sources in Upper Fountain Creek, Colorado, 2007-2008, By Using Multiple Lines of Evidence
}

In May 2007, the U.S. Geological Survey, in cooperation with the Pikes Peak Area Council of Governments, Colorado Department of Public Health and the Environment, Colorado Springs Engineering, and Colorado Springs Utilities, began a study to document the locations, magnitude, and sources of fecal contamination to upper Fountain Creek, Colorado (fig. 1). Upper Fountain Creek extends from the headwaters, near Green Mountain Falls, Colorado, to the confluence of Monument Creek with Fountain Creek in Colorado Springs, Colorado. Measured densities of Escherichia coli (E. coli) in Fountain Creek were more than 126 per 100 milliliters (the Colorado criterion for recreational uses; Colorado Department of Public Health and Environment, 2005) at several sites in the study area. Exceedances occurred during warm-weather months (warm season, June 15 through September 15) in Ruxton Creek (site 9), Fountain Creek downstream from Ruxton Creek (site 10), and Fountain Creek below 8th Street in Colorado Springs (site 15).

Samples collected in the study area generally met the $E$. coli criterion throughout the cool-weather months (cool season, September 16 through June 14) and during the warm season in Fountain Creek upstream from Ruxton Creek. Data indicated that human sources rarely accounted for most $E$. coli observed during exceedances; rather, data indicated that other sources, particularly birds, likely were the dominant source of $E$. coli during exceedances of the standard.

\section{Study Objectives}

In 2008, Fountain Creek was placed on the Colorado 303(d) list of impaired streams because of fecal contamination (Colorado Department of Public Health and Environment, 2008). The objective of this study was to identify major sources of $E$. coli in upper Fountain Creek during
Fountain Creek is a high-gradient stream on the Front Range of the Rocky Mountains in Colorado (fig. 1). The headwaters of Fountain Creek drain Pikes Peak, a major destination for tourism. Fountain Creek is a drinking-water source for the City of Colorado Springs, Colorado, and is used for irrigation, recreation, and other purposes between Colorado Springs and the confluence with the Arkansas River at Pueblo, Colorado. In 2008, Fountain Creek was placed on the Colorado 303(d) list of impaired streams because of fecal contamination. Colorado uses a 30-day geometric mean standard of 126 E. coli per 100 milliliters as its management goal for recreational waters (Colorado Department of Public Health and Environment, 2005).

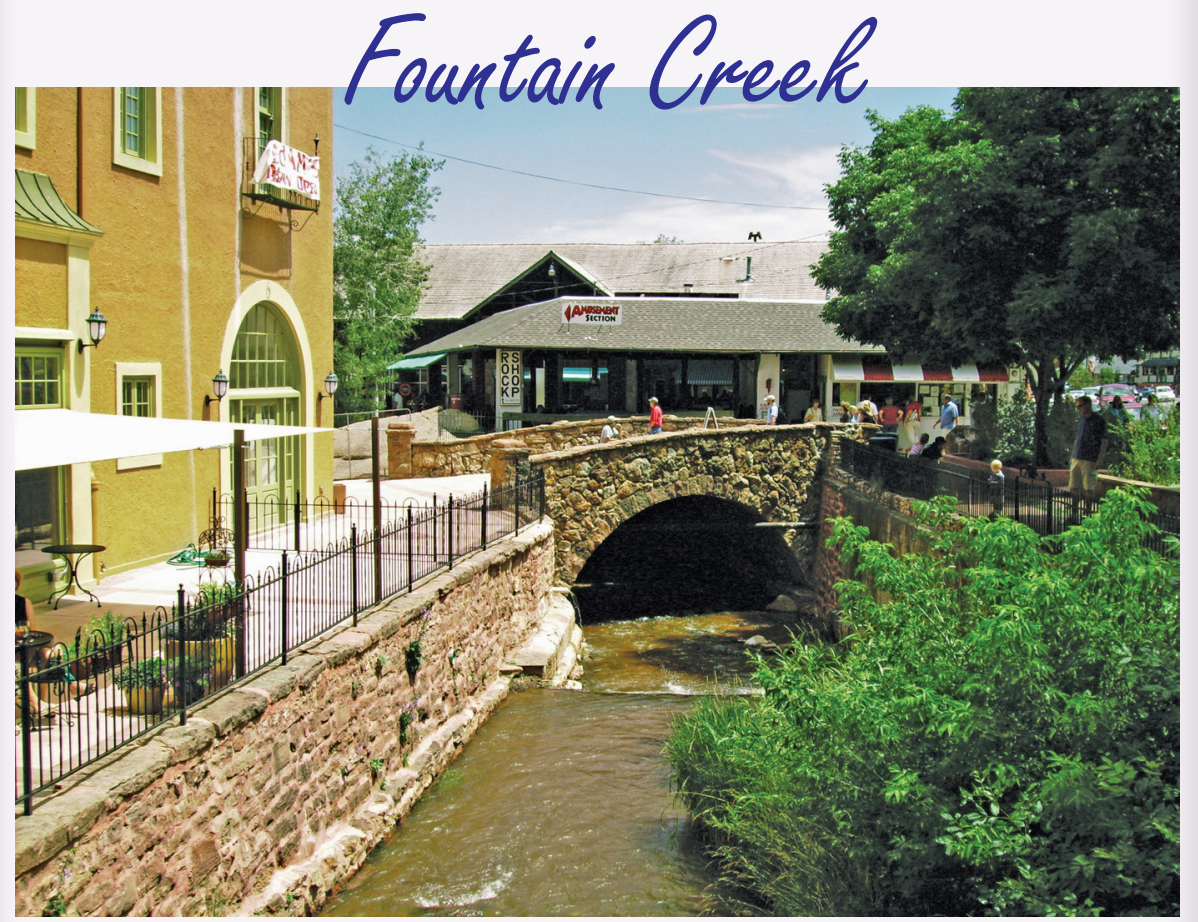

Upper Fountain Creek is mostly undeveloped except for substantial populations around Manitou Springs and Colorado Springs. Likely controllable sources of fecal contamination, identified by local water managers, include humans, horses, grazing cattle, wildlife, and domestic pets. E. coli sampling began at 16 sites during the first year of the study. Based on these data, areas where E. coli tended to exceed the State's recreational water standard were selected to track fecal contamination in more depth during the second year of the study:

- Upstream from Manitou Springs (site 2: Fountain Creek below Green Mountain Falls),

- Within Manitou Springs (sites 7.9, 9, and 10: Fountain Creek above Ruxton Creek, Ruxton Creek at mouth, and Fountain Creek below Ruxton Creek, respectively),

- Between Manitou Springs and Colorado Springs (site 15: Fountain Creek below 8th Street) 


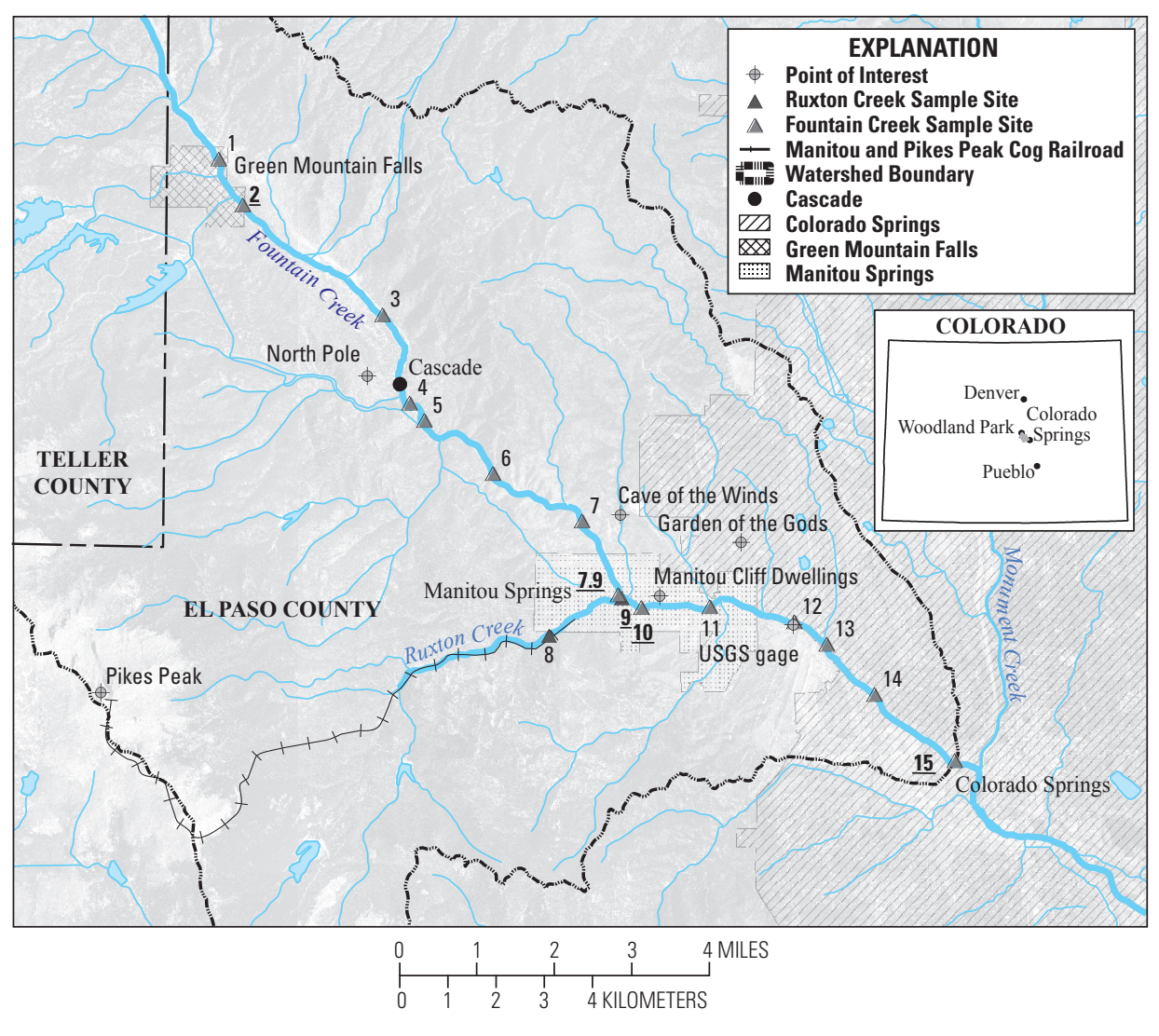

Figure 1. Locations of sampling sites in the Fountain Creek and Ruxton Creek watersheds, Colorado, 2007 to 2008. Various municipalities are shown as shaded areas. Sample sites are indicated with numerals (1 to 15). Numerals that are bold underlined indicate intensivemonitoring sites at which a full suite of analytes was evaluated. exceedances of the State recreational water standard. To meet this objective, a new approach was developed and tested that uses genetic marker analysis for microbial source tracking (MST, see sidebar for definition), along with other information, to evaluate potential contributions of fecal contamination from various sources (Stoeckel and others, 2011). Knowledge of sources will allow water-quality managers to make decisions based on health risks associated with feces from those sources.

\section{Evaluation of Fecal Contamination by Human and Ruminant Sources}

The initial E. coli survey at 16 sites in 2007 (Stoeckel and others, 2011), identified the location where Ruxton Creek enters Fountain Creek as a pivotal point in the watershed (sites 7.9, 9, and 10). At this location, Fountain Creek often changed from achieving to failing to achieve Colorado's standard for in-stream E. coli density. Ruxton Creek accounted for some, but not all, of the fecal contamination at this point. In addition to this location, Fountain Creek below Green Mountain Falls (site 2) had occasional exceedances of the Colorado standard, and Fountain Creek below 8th Street (site 15; the downstream-most site) consistently

\section{Microbial Source Tracking of Fecal Contamination:}

The Clean Water Act of 1972 requires that all waters of the United States be classified according to designated uses (U.S. Environmental Protection Agency, 2010). Each state has its own system of designated uses: examples of these designated uses include habitat for fish and wildlife, industrial uses such as cooling water, and recreation. The major limitation for recreational uses is public health risk caused by fecal contamination. Although the U.S. Environmental Protection Agency (USEPA) currently (2010) is re-evaluating the way that public health risk is measured, the criteria in effect at the time of this research require measurement of Escherichia coli (E. coli) or enterococci, another type of fecal-indicator bacteria.

USEPA puts forth guidance for the states so that each state may regulate its water to meet designated uses. The most-recent criteria that USEPA put forward were in 2004, in support of the BEACH Act of 2000 that covers recreational water quality at coastal and Great Lakes'beaches. These criteria are essentially the same as those put forth in 1986 for swimming beaches and non-swimming recreational uses. The USEPA criteria are published as part of the Code of Federal Regulations and are available at http://www.epa.gov/beaches/.

Although many states have no coastal or Great Lakes beaches, the criteria published by USEPA commonly are applied to inland recreational waters. The State of Colorado created its recreation water standards based generally on the USEPA criteria. The Colorado standard specifies that Class E (existing) recreational waters must maintain a geometric mean concentration of E. coli that is less than 126 per 100 milliliters. In Colorado and other States, the Clean Water Act of 1972 requires adding waterways that do not meet standards for their designated use to a list of "impaired" waterways. Under the Clean Water Act of 1972, existing management of impaired waterways is insufficient to bring E. coli to within standards, a Total Maximum Daily Load (TMDL) plan must be created to manage E. coli contamination in that waterway. 
exceeded the E. coli standard during the warm season. In both years of sampling, $E$. coli densities generally were higher during the warm season than during the cool season (figs. 2 and 3).

Water was tested for total fecal contamination and contamination from human and ruminant sources by use of MST genetic marker tests. If humans or ruminants (cattle, deer, elk, and sheep) were the source of high concentrations of $E$. coli during the warm season, the genetic markers for those animals would increase in the warm season. However, the various MST genetic markers did not increase during the warm season (fig. 3).

During the cool season, MST marker analysis did not exclude any of the evaluated animals (human, ruminant, pet, bird, other nonruminants) as potential sources of fecal contamination. However, because the levels of $E$. coli generally were below the standard during these months, the presence of fecal contamination from any of these sources did not exceed regulations. However, during warm season, MST marker analysis indicated that humans, ruminants, and pets (cats and dogs) could not have been the source of excessive $E$. coli (relative to the standard).

Birds were the only evaluated source that could have contributed this much E. coli without being detected by MST genetic markers. In the area of Manitou Springs, pigeons were observed roosting in large numbers under bridges and buildings near Fountain Creek. In the area between Manitou Springs and Colorado Springs, other birds may be a more likely explanation than pigeons.

Water also was tested for wastewaterassociated chemicals. If human sources of fecal contamination caused increased $E$. coli density then wastewater-associated chemicals might be present. Although these chemicals were detected more often in developed areas of Manitou Springs and Colorado Springs, they were not detected more often during the warm season (high E. coli) than during the cool season (low E. coli). Many samples with high E. coli concentrations had no detectable wastewater chemicals, implying absence or low concentration of human-source fecal contamination.

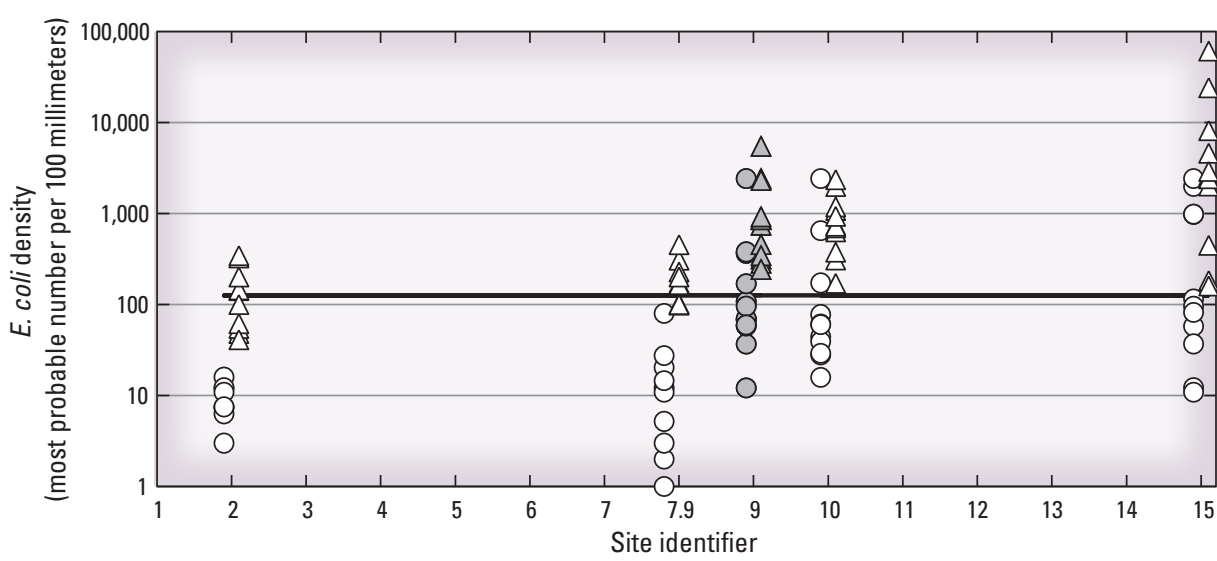

EXPLANATION

$\bigcirc$ Cool season, Fountain Creek

$\triangle$ Warm season, Fountain Creek

$\bigcirc$ Cool season, Ruxton Creek

$\triangle$ Warm season, Ruxton Creek

Colorado Standard

Figure 2. E. coli density measurements during the year-long intensive monitoring, August 2007 through September 2008. For the purposes of this plot, warm season extended from June 15 through September 15, and cool season extended from September 16 through June 14 . Warm season and cool season values are associated with the same sites, but are offset from the true site identifier to enhance visual clarity.

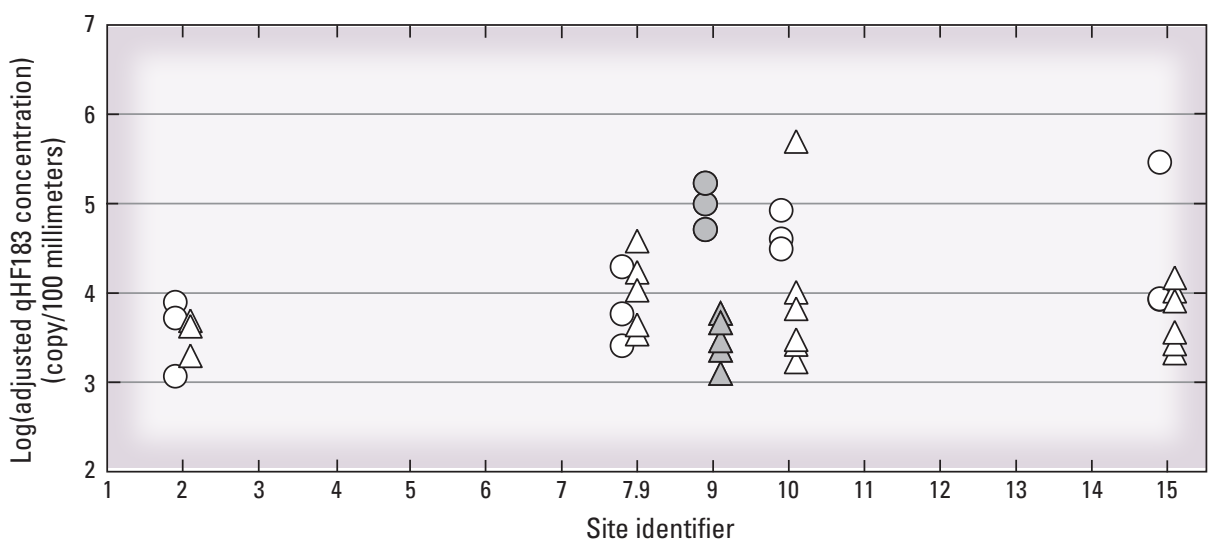

EXPLANATION

Cool season, Fountain Creek

$\triangle$ Warm season, Fountain Creek

Cool season, Ruxton Creek

$\triangle$ Warm season, Ruxton Creek

Figure 3. Example microbial source tracking marker concentration measurements (human-associated marker qHF183) during the year-long intensive monitoring, August 2007 through September 2008. For the purposes of this plot, warm season extended from June 15 through September 15, and cool season extended from September 16 through June 14. Warm season and cool season values are associated with the same sites, but are offset from the true site identifier to enhance visual clarity. 


\section{Conclusions}

The general lack of wastewaterassociated chemicals in the water samples during the warm season supported the finding that humans or ruminants were not the primary cause of fecal contamination to upper Fountain Creek. This lack of wastewater-associated chemicals was not an artifact of analysis; in five samples (20 percent of the samples with high concentrations of $E$. coli), high levels of $E$. coli coincided with detection of human-associated genetic marker, elevated ammonia concentrations and above-backgroundlevel detections of wastewaterassociated chemicals.

The indication that birds were a probable source of $E$. coli contamination during warm season was supported by the data collected. In water samples collected during the warm season and in bird-feces samples, high concentrations of $E$. coli were present but the general-feces MST marker concentration was low relative to other potential fecal sources and humanand ruminant-associated markers were absent. Furthermore, the absence of human-associated wastewater compounds in these water samples was consistent with bird sources. Bird droppings were the only source of $E$. coli that was evaluated that had characteristics consistent with the water data collected.

Human, ruminant, and pet sources would not have been excluded as probable dominant sources of fecal contamination to upper Fountain Creek except through application of the new methods developed for this study. The validation of this approach was supported with additional lines of evidence. The use of microbial source tracking to help understand $E$. coli contamination led to unexpected findings in upper Fountain Creek. The same approach could result in useful information in other areas of Colorado, and in other States, where recreational-water quality standards are exceeded and the sources of contamination are unknown.

\section{References Cited}

Colorado Department of Public Health and the Environment, 2005, Section 303(d) list water-quality-limited segments requiring TMDLs (5 CCR 1002-93): Water Control Commission, regulation no. 93.

Colorado Department of Public Health and the Environment, 2008, The basic standards and methodologies for surface water (5 CCR 1002-31): Water Control Commission, regulation no. 31 .

Stoeckel, D.M., Stelzer, E.A., Stogner, R.W., and Mau, D.P., 2011, Semiquantitative evaluation of fecal contamination potential by human and ruminant sources using multiple lines of evidence: Water Research, v. 45, p. 3225-3244.

U.S. Environmental Protection Agency, 2010, National summary of impaired waters and TMDL information: Accessed April 15, 2011, at http://iaspub.epa.gov/ waters10/attains_nation_cy.control?p_ report_type $=T$.

—Donald Stoeckel

\section{For more information, contact}

Southeast Colorado Chief, USGS Colorado Water Science Center

201 East 9th Street

Pueblo, CO 81003

Phone: (719) 544-7155

Or visit the Colorado Water Science Center Web site at http://co.water.usgs.gov/

This publication is available online at URL http://pubs.usgs.gov/fs/2011/3095/

\section{Contact information}

David Mau

Southeast Colorado Hydrologic Studies Chief

USGS Colorado Water Science Center

Phone: 719-544-7155

dpmau@usgs.gov

Donald Stoeckel

$\mathrm{PhD}$, Principal Investigator

Phone: 614-670-9302

don@dsH2O.com 